\title{
Financialization as a Factor Constraining Economic Growth and Standard of Living Improvement in Poland
}

\section{Introduction}

Basing the economic systems of EU countries on the doctrine of market liberalism caused an idealized market to be perceived as the best way to maximize profits, not from the production of material goods and their distribution, but through the provision of broadly defined financial services. This was evidenced by the development of a range of financial products (quasi-money), removal of financial capital from the sphere of material goods production and investing it in risky financial transactions, giving impetus to the process of financialization, as it was described by P. H. Dembinski [5]. The development of information and communication technologies further accelerated this process. This free-market euphoria and building a future based on an investment utopia was also served by erroneous theories, supported by mathematical models and the Bank of Sweden Prize in Economic Sciences in memory of Alfred Nobel, supposedly indicating effective ways of investing (by businesses and residents) in capital markets.

Examples of such award-winning theories and models include work by co-creators of so-called financial engineering or financial mathematics - Myron Scholes and Robert Merton (they received the Nobel Prize in Economics in 1997). Their model for pricing derivatives, focusing on long term contracts, was to help investors minimize investment risk. It soon became apparent that these were false hopes, since an investment fund called Long-Term Capital Management that they founded on this supposedly profitable strategy quickly failed and investors lost

* Andrzej Frycz Modrzewski Cracow University

** AGH University of Science and Technology 
USD 4.6 billion [24, p. 41]. E. Prescott's (Nobel laureate in economics in 2004 for his work on business cycles) theory also proved to be false. In 2000, he asserted with the help of economic theory and econometrics that financial markets are rational (they function rationally). A few months later, the "internet bubble" burst with share prices dropping 50\%. This fact can be regarded as a disaster from which some financial markets, such as Nasdaq, have not recovered until this day [5, p. 17].

The financial crisis that started in 2008 shows that financialization, as the direct cause of this crisis, not only shook the belief in free markets, but also showed that neoliberal theories, as a basis for economic processes, despite the development of an extensive methodology (i.e. statistical and mathematical models) which is intended to aid making rational decisions, do not ensure sustainable economic growth and standard of living improvement for society as a whole. It also indicates that studies limited to direct causes of financialization and its impact on financial crises are inadequate. A thorough explanation of the sources of this process and its socio-economic impact under the current process of globalization, is required.

Recognizing that these problems are pertinent to the realization of objectives that were at the foundation of European integration (i.e. prosperity, peace, democracy and human rights), this article shows the effects of financialization on achieving sustainable economic growth and living standards improvement of residents of countries with market economies, including Poland as an EU member. It also indicates a way out of the existing negative approaches forming the basis of financialization.

\section{Main sources of financialization}

A characteristic feature of modern liberal market capitalism, which is called "casino capitalism" [21], "stock market capitalism" or the epoch of finance, in which "finance primarily finances finance" [12], are frequent financial crises turning into economic crises. Many authors (such as Stiglitz [20], Dembinski [5] and Otte [16]) seeing financialization as the direct cause of contemporary financial crises, analyze its symptoms, direct causes and effects of economic growth.

By contrast, Song Hongbing [9, 10] does not focus his research on causes, manifestations and direct consequences of financialization but on its sources. The primary source of financialization and financial crises, turning into global economic crises, is the issuance of money out of nothing by private central banks. Consequently, this led to the introduction of floating exchange rates and casino capitalism. 
Studies of financialization show that the residents of many countries, and even economists, are not aware of the socio-economic effects of the existence of private central banks, even in countries such as the United States or Great Britain, and of giving them full control over the issuance of money.

The private UK central bank was founded in 1694. The primary reason for creating the Bank of England was the desire to convert the debt of the king (William III) and his court into eternal government debt set up as a mortgage based on tax revenue. Thus, the Bank of England gained the exclusive right to issue national currency (it was given this exclusive right). The uniqueness of this project consisted in the absolute binding of issuing national currency with public debt. Whenever the need arose to issue new money, the only solution was to increase public debt [9, pp. 16-19].

The need to repay the interest on this debt and the need for continued economic growth led to an increase in demand for money and loans. Hence, both public and private debt continues to grow. The interest charged on loans ends up in bankers' wallets and the burden of repayment is borne by ordinary people.

Similarly to the Bank of England, the U.S. Federal Reserve is a private bank, which means that the Fed is not only not a federal bank, but it is also not a reserve. Starting from December 23, 1913, the U.S. federal government does not have the right to issue money and does not issue the U.S. dollar. After the assassination of President Kennedy in 1963, the U.S. government lost the authority to issue the "silver dollar", the only means of payment that the government was still entitled to issue at that time. It is noteworthy that president Kennedy was determined to keep this right as stated by Song Hongbing based on reliable U.S. documents [9, p. 62].

The Federal Reserve was designed to have all the characteristics of a private central bank and did not differ in any way from the private Bank of England that acted as the central bank of Great Britain. It was stipulated that private shareholders will be the owners of the Federal Reserve, which gave them the opportunity to reap huge profits from the issuance of money. Regional banks that make up the Fed are also not part of government structures. The idea that the government was entitled to $20 \%$ of its shares was rejected. According to Song Hongbing, the name "Federal Reserve System" was used in the Federal Reserve Act that founded the Fed in order to hide the true nature of this private central bank, as well as to comply with the constitution, which states that "The Congress shall have power to coin money and regulate the value thereof" [23, Art. 1, Sec. 8].

The Federal Reserve Act was passed in great haste. Most of the congressmen and senators did not even have time to carefully read the contents of the Act and to make appropriate amendments since the final draft was printed on December 22 at 4:30 AM, the final reading took place at $7 \mathrm{AM}$ and voting in Congress 
began at $11 \mathrm{PM}$ all on the same day. The next day (December 23) the Act passed the Senate and on the same day, an hour after its adoption, it was signed into law by President W. Wilson. Its signing generated an explosion of joy on Wall Street and in the London City financial district.

The Federal Reserve Act was passed in such a haste that only a few congressmen, including $\mathrm{Ch}$. A. Lindbergh, were able to publicly point out its flaws. A passage from Lindbergh's speech at the meeting of Congress should certainly be remembered: "The greatest crime of Congress is its currency system. The worst legislative crime of the ages is perpetrated by this banking bill. The caucus and the party bosses have again operated and prevented the people from getting the benefit of their own government" (Ch. Lindbergh, Speech in Congress, December 23, 1913, quoted by [9, pp. 82-83]).

Senator Aldrich also noted significant flaws in this act. In an interview for The Independent in 1914 he said: "Before the passage of this Act, New York bankers could only dominate the reserves of New York. Now we are able to dominate the bank reserves of the entire country" [9, p. 83].

The introduction of the Federal Reserve Act meant that after more than a century of the bankers' struggle with the U.S. government, international bankers finally achieved their goal - they gained total control over the right to issue currency in the U.S., thus control finance, trade and politics in America.

Following his presidency, the twenty-eighth president of the United States W. Wilson, who hurriedly signed the Federal Reserve Act into law, noticed his mistake and said: "A great industrial nation is controlled by its system of credit. Our system of credit is concentrated. The growth of the nation, therefore, and all our activities are in the hands of a few men." (as cited by Hongbing [9, p. 61]). He also admitted that he had been cheated and that he was allowed to nominate only one member of the supervisory board of the Federal Reserve, all others were elected by New York bankers, which means that the government is completely dependent on the bankers. Plagued by remorse he confessed (before his death): "I have unwittingly destroyed my country" [9, p. 89].

Control of issuing money by private banks has always been the goal of bankers. The effects of this were understood not only by bankers, but also by nineteenth century leaders of the United States and other countries.

Napoleon Bonaparte's statement on this point dating from 1815 is clear. He stated that "When a government is dependent upon bankers for money, they and not the leaders of the government control the situation, since the hand that gives is above the hand that takes... Money has no motherland; financiers are without patriotism and without decency; their sole object is gain" (R. McNair Wilson, Monarchy or Money Power, London 1933, p. 68 as cited by Hongbing in $[9$, p. 25]). 
A similar view was held by the barely thirty-three year old author of the Declaration of Independence (the third president of the United States) Thomas Jefferson, undoubtedly representing the interests of most citizens. Worrying about their future he warned: "If the American people ever allow private banks to control the issue of currency, first by inflation, then by deflation, the banks and corporations that will grow around them will deprive the people of all property until their children wake up homeless on the continent their fathers conquered." (T. Jefferson's statement from 1787, quoted by Hongbing [9, p. 39]).

He also made a clear and decisive statement in 1802: "I believe that banking institutions are more dangerous to our liberties than standing armies. Already, they have raised up a moneyed aristocracy that has set the government at defiance. The issuing power should be taken from the banks and restored to the people, to whom it properly belongs." (T. Jefferson's statement from 1802, quoted by Hongbing [9, p. 39]).

The sixteenth U.S. President Abraham Lincoln also perfectly understood the threat to the country and welfare of residents resulting from the printing of money by private banks, that is why during the Civil War, he issued $\$ 450$ million of a new currency called "Lincoln's greenback". The issuance aroused a negative reaction of British bankers, as stated in the London Times (a newspaper representing the interests of bankers): "If this mischievous financial policy, which has its origin in North America, shall become indurated down to a fixture, then that Government will furnish its own money without cost. It will pay off debts and be without debt. It will have all the money necessary to carry on its commerce. It will become prosperous without precedent in the history of the world. The brains, and wealth of all countries will go to North America. That country must be destroyed or it will destroy every monarchy on the globe." (quoted by Hongbing in [9, p. 53]).

In view of the profits from the issue of money by private banks, the issuance of "Lincoln's greenback" was opposed by the American Bankers Association. It expressed this in a letter to its members saying: "It is advisable to do all in your power to sustain such prominent daily and weekly newspapers, especially the agricultural and religious press, as will oppose the greenback issue of paper money and that you will also withhold patronage from all applicants who are not willing to oppose the government issue of money. To repeal the Act creating bank notes, or to restore to circulation the government issue of money will be to provide the people with money and will therefore seriously affect our individual profits as bankers and lenders. See your congressman at once and engage him to support our interest that we may control legislation." (From a letter by the Bankers Association of New York, Philadelphia and Boston sent to bankers of all states in 1877, quoted by Hongbing [9, p. 59]). 
It turns out that the issue of state debt-free money, the "Lincoln's greenback", brought a great benefit to the state. This solution has saved the government from taking out high-interest loans from private banks. Thanks to this, the industry, construction companies involved in the development of railways, agriculture and trade gained access to cheap credit. Based on information issued by the U.S. Treasury secretary in 1972, by issuing its own currency, without the need to pay interest to private bankers, the government saved four billion U.S. dollars in interest payments (M. Sikler, Abraham Lincoln and J. F. Kennedy, "Michael" 2003 no. 4 , quoted by Hongbing [9, p. 55]).

Although many U.S. presidents and congressmen warned against the danger of putting money supply in the hands of the financial elite, it was finally given to a private bank.

An analysis of the Federal Reserve System clearly shows that the democratic system that Americans are so proud of is not resistant to the threat of government by money, because international finance, using the right to issue money, is gaining control of the country too.

This general conclusion makes it reasonable to consider the situation in Poland resulting from the issuance of money in the former People's Republic of Poland and today.

\section{Brief characteristics of money issuance in Poland during the former People's Republic of Poland (PRL) and after 1990}

In Poland, during the period after World War II until the premarket transformation, the issue of money ("złoty") was not based on debt. Poland's central bank (NBP) and other banks (except a few cooperatives) located throughout the country were government owned. In its activities, none of these banks were motivated by profit. Quite the contrary. Prices of loans in the Polish banking system were set at a level that only covered the banks' own operating cost. They hovered around $2 \%$ until 1958, which provided cheap credit to rebuild the country after the devastation of war (as part of the three-year plan) and invest in capitalintensive production (as part of a six-year plan, which laid the foundations of the Polish economy). After 1958, interest on operating loans was increased to $4 \%$ whereas interest on investment loans was left unchanged. Until 1969, investors could benefit from low interest rates ( $2 \%$ per year) loans for central investments. The price of credit could be increased to $3 \%$ only as punishment in case the investor was not fulfilling the credit agreement (i.e. the investment was not 
carried out according to plan). Additionally, loans were easily accessible for all types of investments, i.e. central, cooperative and business investments (an analysis of loans well-documented with empirical data was presented by F. Skalniak [18]). In the mid-1970s a variation in the prices of loans by type of investment was introduced, with a preference for so-called quick-return investments. Discount rates were raised to $8 \%$ for evaluating the efficiency of investments to be financed using bank loans. Low credit prices favored investments. Along with the transformation of the Polish economy (after 1989), the price of bank loans in Poland rose to a very high level. In recent years, the real price of loans in private banks, of which over $80 \%$ are foreign-owned, has been hovering around $14 \%$ (in the first years of transformation, the nominal price of credit was higher and amounted up to $120 \%$ ). Moreover, loans from Polish state-owned banks sold to foreign investors are very difficult to get. Banks owned by foreign capital often demand assets of the potential debtor company valued at two to three times the value of the loan, as collateral for the loan. This not conducive to investing, nor creating and maintaining jobs.

The example of PRL shows that a country in which the government issues its own money can not only quickly, without incurring foreign loans, rebuild itself after the devastation of a war, but also eliminate unemployment. Foreign debt was not introduced in PRL until the 1970s when Edward Gierek took foreign loans for investments to modernize the economy.

To summarize this discussion concerning the issuing of money by private central banks, it is worth noting that at present China is a country in which the government directly issues currency (there is a state-owned banking system). In this way both the government and the public can save huge amounts of money by not having to repay interest on debt. This is one of the main causes of China's rapid economic growth over the last 30 years and it reinforces the belief that China should never agree to their government giving up the right to issue money to a private bank, which would use state bonds as a basis for printing domestic currency. Whether China's example will become a model to imitate depends on the awareness, strength and unity of politicians and leaders of countries who will be able to break free from the dictates of bankers. It also hinges on economists from prestigious universities worldwide, who would want to honestly explain the issuance of currency in economics textbooks and classrooms, and not - as is the case now - remain silent on the subject.

Giving the right to issue money to private banks, deregulation and the formation of giant financial entities, which (given the scope of their activities) should not be called "banks", means that they are capable of controlling economic recessions and financial crises to reap huge profits. 


\section{Control of recessions by banks}

An analysis of crises shows that banks' control of recessions always follows the same scenario. First, banks relax their lending policies. They offer various forms of cheap credit, even nag their customers to borrow money, which ultimately inflates a speculative bubble. Afterwards, these banks suddenly suspend lending and a recession begins. There is a sudden drop in prices of fixed and various other assets. Once the price of high-value assets drops to a very low level, such as $10 \%$ of their normal value, the same bankers make bulk purchases at these extremely low prices. In banker's jargon this is called "sheep shearing". Where there is a private central bank "sheep shearing" reaches enormous proportions. Asian countries in 1997, except China that had no foreign-owned private banks, provide an example of such "sheep shearing".

The elimination of the gold standard facilitates control of recessions and "sheep shearing" since in the absence of a gold standard, as rightly stated by A. Greenspan, there is no way of protecting savings from inflation: "The Gold Standard hard stops the momentum of inflation." (A. Greenspan, Gold and Economic Freedom, New York 1967, pp. 100-101, quoted by Hongbing [9, p. 117]). This is why bankers sought to completely remove gold from its position in the monetary system. This was done in three stages. First, gold was eliminated from U.S. circulation and monetary exchange. Second, gold was eliminated from foreign exchange transactions (as part of the Bretton Woods system introduced in 1944). The third phase ended with President Nixon moving away from the Bretton Woods arrangements in 1971. This decision made the U.S. dollar a debt certificate. Despite the elimination of the gold standard, bankers fear gold as a store of reserves, and therefore control its prices.

Most people believe that the transition of an economy through boom and bust cycles is a regularity that governs economies and that it must be so. Such reasoning is erroneous, because the fundamental cause of this problem is the control of the currency supply by world bankers. They decide when to loosen monetary policy, and when you tighten it. Undoubtedly, the stock market crash of 1929 and other crises were been planned by the Federal Reserve and European bankers.

By analyzing the current financial crisis, which came from the United States, it is difficult to believe that A. Greenspan, for many years governor of the Federal Reserve, who perfectly understood the rules governing the global economy, known for his reliable, even astonishing precision in forecasting trends in its transformations and development, could not foresee that the policy of the Reserve headed by him leads to a crisis.

As a result of giving the issuance of money to private banks, now in countries with market economies, such as the United States and EU countries, the principle applies that economic growth must be fueled by debt. It consists in the fact that 
debt creates money, money promotes greed, greed increases debt; there is a debt implosion, the implosion results in deflation, which in turn leads to a recession. Therefore, questions arise whether, in such a situation, the governments of individual countries, including EU countries, are able to pursue a policy of sustainable economic growth, if their economies can be knowledge-based and ensure a steady improvement of living standards of the general population, or if these concepts, in the present reality, are only an expression of dreams and unrealistic visions of theoretical economists.

Answering this question necessitates, among others, showing the impact of financialization on economic growth and living standards.

\section{Financialization's impact on economic growth and standard of living improvement in Poland as an EU country}

For countries to achieve economic growth and development, a constant supply of monetary capital into the sphere of production of goods to meet the needs of society is required. This type of investment eliminates "casino capitalism" [21] and requires proper regulations concerning the issuance of money and the functioning of financial markets, because high profits in the financial markets are becoming a high alternative cost for investments in the sphere of material production and investments in knowledge. The creation of quasi-money and the development of "casino capitalism" leads to ignoring the basic law of economics, which is: wellbeing of society comes from work and the production of goods. Respecting this law implies that the impetus for development should result from innovations in the technological field, and not from preparing financial banking products for the needs of "casino capitalism".

The process of financialization should not be continued because it results in high public debt and budget deficits, high unemployment, highly diverse incomes and increasing poverty. This assertion is based on empirical data from the years of the current financial crisis and years proceeding it (Table 1).

Table 1

Public debt (as a percentage of GDP) in selected EU countries in 2007-2012

\begin{tabular}{|l|r|r|r|r|r|}
\hline \multicolumn{1}{|c|}{ Country } & $\mathbf{2 0 0 7}$ & $\mathbf{2 0 0 9}$ & $\mathbf{2 0 1 0}$ & $\mathbf{2 0 1 1}$ & $\mathbf{2 0 1 2}$ \\
\hline The euro area & 66.0 & 78.2 & 83.9 & 86.5 & 87.3 \\
\hline Germany & 65.0 & 73.2 & 76.5 & 79.5 & 81.0 \\
\hline France & 63.8 & 77.6 & 83.2 & 86.1 & 87.1 \\
\hline
\end{tabular}


Table 1 cont.

\begin{tabular}{|l|r|r|r|r|r|}
\hline \multicolumn{1}{|c|}{ Country } & $\mathbf{2 0 0 7}$ & $\mathbf{2 0 0 9}$ & $\mathbf{2 0 1 0}$ & $\mathbf{2 0 1 1}$ & $\mathbf{2 0 1 2}$ \\
\hline Greece & 95.7 & 115.1 & 120.4 & 120.6 & 117.7 \\
\hline Italy & 103.5 & 115.8 & 116.9 & 116.5 & 114.6 \\
\hline Spain & 36.2 & 53.2 & 65.9 & 71.9 & 74.3 \\
\hline Portugal & 63.6 & 76.8 & 70.5 & 70.0 & - \\
\hline Ireland & 25.0 & 64.0 & 77.9 & 82.9 & 83.9 \\
\hline Belgium & 84.2 & 96.7 & 100.6 & 101.4 & 100.6 \\
\hline Luxembourg & 6.7 & 14.5 & 18.3 & 23.9 & 23.9 \\
\hline Netherlands & 45.5 & 60.9 & 67.2 & 69.6 & 72.5 \\
\hline Austria & 59.5 & 66.5 & 70.2 & 72.6 & 73.8 \\
\hline Finland & 35.2 & 44.0 & 48.3 & 52.2 & 54.4 \\
\hline Slovenia & 23.4 & 35.9 & 39.6 & 42.0 & 42.7 \\
\hline Cyprus & 58.3 & 56.2 & 45.4 & 44.2 & 44.2 \\
\hline Malta & 61.9 & 69.1 & 68.6 & 68.0 & 67.3 \\
\hline Slovakia & 29.3 & 35.7 & 40.8 & 42.5 & 42.2 \\
\hline Poland & 48.4 & 51.5 & 53.9 & 59.5 & - \\
\hline
\end{tabular}

Source: [6, p. 72; 7, pp. 555-556, 574; as well as data from EU's stabilization programs]

Data in the table above shows that EU countries, even those considered to be highly advanced (such as Germany, France and Belgium), have a high public debt. In addition, the public debt shows no downward trend. Poland is also one such country. In 2011, the Polish public debt went up to around 900 billion zł. This debt calculated on an accrual basis would represent $220 \%$ of GDP [19].

In Poland, the entire transformation period is characterized not only by high public debt but also high budget deficits and high unemployment at well above the EU average. The last budget surplus was recorded in 1989 (in PRL) before the start of the transition, when the issuance of money belonged to the state; the state issued money and banks were state-owned. During the transformation of the Polish economy, a negative trade balance with major foreign trade partners, as a result of the opening of borders to the avalanche of imports to Poland (in the period of the so-called Balcerowicz plan), also made an significant contribution to the formation of a permanent budget deficit. In 1990, the negative trade balance amounted to USD 4793 million USD, and in 2010 it was USD 13119 million. Such a high negative balance of trade can be associated not only with shortages of goods on the Polish market but also no access to credit for Polish companies, 
a sellout of the best and most modern Polish companies to foreign capital, which led to the liquidation of many of them. This problem was thoroughly shown by W. Kieżun, who gave a list of modern Polish companies which have experienced "hostile takeovers" by foreign capital during the period of rapid privatization and now no longer exist [11, pp. 136-138], and also by J. Tittenbrun in a publication rightly called the four-volume work [22].

Privatization of Polish companies took place without a strategy to ensure long-term economic growth and development of the country. The only criterion was that everything that is state-owned and Polish is bad, whereas under D. Tusk's government the criterion was saving the state budget. Hence, now only 17 of the largest 100 companies in Poland are in fact Polish [11, p. 152]. Despite revenues from privatization, Polish foreign debt has been increasing throughout the transition period (Table 2).

Table 2

Polish foreign debt

\begin{tabular}{|c|c|c|c|c|c|c|}
\hline \multicolumn{1}{|c|}{ Parameter } & $\mathbf{2 0 0 6}$ & $\mathbf{2 0 0 7}$ & $\mathbf{2 0 0 8}$ & $\mathbf{2 0 0 9}$ & $\mathbf{2 0 1 0}$ & $\begin{array}{c}\mathbf{2 0 1 0} \\
\text { minus } \\
\mathbf{2 0 0 6}\end{array}$ \\
\hline $\begin{array}{l}\text { Total external } \\
\text { debt (in million } \\
\text { Euro), including: }\end{array}$ & 128870 & 159106 & 174265 & 195025 & 236000 & 107130 \\
\hline $\begin{array}{l}\text { - public sector } \\
\text { debt (\%) }\end{array}$ & 40.0 & 33.8 & 27.4 & 31.2 & 36.2 & -3.8 \\
\hline $\begin{array}{c}\text { - banking sector } \\
\text { debt (\%) }\end{array}$ & 13.8 & 17.2 & 24.5 & 22.0 & 20.6 & 6.8 \\
\hline $\begin{array}{l}\text { - NGO sector and } \\
\text { non-banking } \\
\text { sector debt (\%) }\end{array}$ & 45.5 & 45.5 & 47.0 & 44.9 & 40.4 & -5.1 \\
\hline $\begin{array}{l}\text { Share of external } \\
\text { debt (\% GDP) }\end{array}$ & 47.3 & 51.0 & 57.8 & 62.8 & 53.8 & 6.5 \\
\hline
\end{tabular}

Source: based on $[4 ; 8]$

Furthermore, the entire transition period was characterized by low growth rates (as measured by \% increase in GDP), which were negative in 1990 and 1991, in 1992 it was only 2.6\% (Table 3). Only in 1995, the growth amounted to $7 \%$. At this rate of growth, one can hardly expect a reduction in unemployment, a policy of sustainable development, the creation of a knowledge-based economy or a significantly reduction in the budget deficit. 
Table 3

GDP growth rate, public debt and unemployment rate in Poland in 1990-2011

\begin{tabular}{|c|c|c|c|}
\hline Year & $\begin{array}{c}\text { GDP growth rate } \\
{[\%]}\end{array}$ & $\begin{array}{c}\text { Public debt } \\
{[\text { billion zt] }}\end{array}$ & $\begin{array}{c}\text { Unemployment rate } \\
{[\%]}\end{array}$ \\
\hline 1990 & -19.1 & 53.1 & 6.1 \\
\hline 1991 & -7.1 & 65.8 & 11.5 \\
\hline 1992 & 2.6 & 97.9 & 13.6 \\
\hline 1993 & 3.6 & 133.9 & 15.7 \\
\hline 1994 & 5.2 & 152.2 & 16.0 \\
\hline 1995 & 7.0 & 167.2 & 14.9 \\
\hline 1996 & 6.0 & 189.0 & 13.6 \\
\hline 1997 & 6.8 & 221.6 & 10.5 \\
\hline 1998 & 4.8 & 237.4 & 9.6 \\
\hline 1999 & 4.1 & 278.2 & 13.0 \\
\hline 2000 & 4.2 & 288.3 & 15.0 \\
\hline 2001 & 1.1 & 314.6 & 18.1 \\
\hline 2002 & 1.4 & 352.6 & 20.0 \\
\hline 2003 & 3.8 & 408.6 & 19.0 \\
\hline 2004 & 5.3 & 440.5 & 17.6 \\
\hline 2005 & 3.5 & 477.0 & 14.9 \\
\hline 2006 & 5.8 & 506.2 & 11.2 \\
\hline 2007 & 6.7 & 527.4 & 9.5 \\
\hline 2008 & 3.8 & 569.9 & 12.1 \\
\hline 2009 & 1.7 & 687.6 & 13.2 \\
\hline 2010 & 3.8 & 776.8 & \\
\hline 2011 & 4.3 & 880.7 & \\
\hline & & & \\
\hline & & & \\
\hline
\end{tabular}

Source: [14]

Empirical data shows that unemployment in Poland throughout the period of transition remains at two-digit levels. At the outset of the Balcerowicz plan (in January 1990) the unemployment rate was only 0.3\%, and already in December 1990 it was $12.2 \%$. In the next two years, it grew to $16 \%$ as a result further bankruptcies of state-owned enterprises and their being subject to "hostile takeovers" [11]. In 2003, the unemployment rate reached 20\%. Unemployment levels fell only after the Polish accession to the EU, when a large group of young Poles left to seek work in EU countries. Therefore, the twenty-year transition period in employment and population policies deserves a definite negative assessment. 
Financialization as a Factor Constraining Economic Growth...

Table 4

Emigration from Poland in 2004-2009 in thousands of people

\begin{tabular}{|l|r|r|r|r|r|r|r|}
\hline \multicolumn{1}{|c|}{ Country } & $\mathbf{2 0 0 4}$ & $\mathbf{2 0 0 5}$ & $\mathbf{2 0 0 6}$ & $\mathbf{2 0 0 7}$ & $\mathbf{2 0 0 8}$ & $\mathbf{2 0 0 9}$ & $\begin{array}{c}\text { 2009 } \\
\text { minus } \\
\mathbf{2 0 0 4}\end{array}$ \\
\hline Great Britain & 150 & 340 & 580 & 990 & 650 & 555 & 405 \\
\hline Germany & 385 & 430 & 450 & 490 & 490 & 415 & 30 \\
\hline Ireland & 15 & 76 & 120 & 200 & 180 & 140 & 125 \\
\hline Netherlands & 15 & 43 & 55 & 98 & 108 & 84 & 69 \\
\hline Italy & 59 & 70 & 85 & 87 & 88 & 85 & 26 \\
\hline Spain & 26 & 27 & 44 & 80 & 83 & 84 & 58 \\
\hline Total & 650 & 986 & 1334 & 1945 & 1599 & 1363 & 713 \\
\hline
\end{tabular}

Source: [2]

Very high unemployment rates and low wages for workers that persist in Poland undoubtedly constitute a major reason for many people moving abroad (Table 4). Furthermore, low wages of workers in Poland compared to other countries are an expression of total departure from the goals of the "Solidarity" movement in PRL to fight for decent wages and human dignity. Table 5 shows a comparison of wages in Poland, selected EU countries and the U.S. in 2010.

Table 5

Average gross hourly wages in selected EU countries, the United States and Poland in 2010 in USD (based on an average annualized rate)

\begin{tabular}{|l|c|c|c|}
\hline \multicolumn{1}{|c|}{ Country } & Wages in USD & $\begin{array}{c}\text { Country minus } \\
\text { Poland }\end{array}$ & $\begin{array}{c}\text { Wages in Poland as a } \\
\text { percentage of wages } \\
\text { in other countries }\end{array}$ \\
\hline Norway & 55.03 & 46.09 & 16.25 \\
\hline Denmark & 53.73 & 44.79 & 16.64 \\
\hline Austria & 43.17 & 34.23 & 20.71 \\
\hline Belgium & 42.17 & 33.23 & 21.20 \\
\hline Netherlands & 38.47 & 29.53 & 23.24 \\
\hline Sweden & 38.80 & 29.86 & 23.04 \\
\hline France & 38.80 & 29.86 & 23.04 \\
\hline Great Britain & 36.55 & 27.61 & 24.46 \\
\hline Ireland & 35.06 & 26.66 & 25.54 \\
\hline Italy & 32.10 & 23.16 & 27.85 \\
\hline
\end{tabular}


Table 5 cont.

\begin{tabular}{|l|c|c|c|}
\hline \multicolumn{1}{|c|}{ Country } & Wages in USD & $\begin{array}{c}\text { Country minus } \\
\text { Poland }\end{array}$ & $\begin{array}{c}\text { Wages in Poland as a } \\
\text { percentage of wages } \\
\text { in other countries }\end{array}$ \\
\hline Spain & 24.55 & 15.61 & 36.41 \\
\hline USA & 20.56 & 11.62 & 43.48 \\
\hline Greece & 13.10 & 7.84 & 68.24 \\
\hline Portugal & 10.29 & 1.35 & 86.88 \\
\hline Poland & $\mathbf{8 . 9 4}$ & $\mathbf{0}$ & $\mathbf{0}$ \\
\hline
\end{tabular}

Source: [1]

Empirical data shown in the table above shows that promises of carrying out a market-oriented transformation resulting in Poland's rapid development and a wonderful capitalist future for the society did not come true. The public was deceived by the Solidarity movement and structures of government derived from it, because we are not a country of high economic growth, and besides, it does not translate into an improvement in standard of living of the general population, as shown by employees' wages in Poland compared to other countries and the percentage of population living in relative poverty (Table 6). According to the Central Statistical Office (GUS) relative poverty rate is determined by a minimum (monthly) subsistence on $466 \mathrm{zt}$ for a single-person household and $1257 \mathrm{zł}$ for a four-person farming-based household.

Table 6

Polish people living in relative poverty in years 2000-2010

\begin{tabular}{|c|c|c|}
\hline Year & Percentage of population & Difference (given year - 2000) \\
\hline 2000 & 17.1 & 0 \\
\hline 2001 & 17.2 & 0.1 \\
\hline 2002 & 18.4 & 1.3 \\
\hline 2003 & 20.4 & 3.3 \\
\hline 2004 & 20.3 & 3.2 \\
\hline 2005 & 18.1 & 1.0 \\
\hline 2006 & 17.7 & 0.6 \\
\hline 2007 & 17.3 & 0.2 \\
\hline 2008 & 17.6 & 0.5 \\
\hline 2009 & 17.3 & 0.2 \\
\hline 2010 & 17.1 & 0.0 \\
\hline
\end{tabular}

Source: [3, p. 3] 
This data shows that during the last 10 years, the percentage of Poland's population living in relative poverty has not only not decreased but it has in fact increased.

So-called working poor, who receive a minimum wage that is among the lowest in the EU, are also common in Poland. This corresponds to a net income of only $1111 \mathrm{zt}$ per month. Such a low minimum wage does not meet the criterion for fair wages, which the Council of Europe Committee of Experts set at $68 \%$ of the average wage in a given country's economy. In Poland, the minimum wage during the entire transformation period did not exceed $40 \%$ of the average wage. Such low wages in Poland are justified neither by productivity nor working time [13, pp. 43-52].

A worrying phenomenon in countries with market economies, including Poland, is a steady increase in income disparity. The income gap is already very high, yet it continues to grow not only in the so-called rich countries but also in poor ones, including new EU members such as Poland, which until 1990 was an egalitarian country, with a relatively not wealthy and not diverse society in terms of income and now it stands out in terms of the highest income disparity (with the second highest income disparity in the EU). "Rich Poles match the wealth of financial elites in the West, whereas communities belonging to the middle class or the poor (the unemployed and the so-called working poor and their families) are in a vastly inferior position compared with their counterparts in most countries of the Community" [17, p. 9].

\section{Summary}

The sources and effects of financialization on economic growth and living standards of the population of Poland, as an EU country, lead to the following general conclusions:

1. A growth model based on money owed and a budget deficit, implemented in countries with market economies, including Poland, is not appropriate, since it does not ensure: sustainable economic growth, implementation of the principles of a knowledge-based economy, elimination of unemployment and poverty, and a steady improvement in the living standards of the general population.

2. Control over issuing currency by private banks is the highest form of monopoly. Only if a state issues and controls money, is it possible to provide a fair basis for the functioning of society.

3. Currently, banks provide a large number of complex financial products (innovations) and they are able to create debt using different tools. This financial money has the same purchasing power as real money. 
4. Foreign banks, using financial money, often implicitly, involve themselves in the process of issuing money even in countries where it is issued by the state. They also fund research into the creation of new forms of currency and models of the allegedly high rates of return on investments in financial markets. In this way, they have control over inflation and deflation, and thus over financial and economic crises.

5. Countries' financial security should be an area of strict control and supervision by their governments. Economies should focus on the production of material wealth by fair work that is remunerated based on the effects of work that is done.

6. National governments and politicians who create laws in parliaments should find the strength to oppose the aims of international bankers to control issuance of money on a global scale.

7. If societies of the world are not to become the slaves of world bankers and the global financial elite, it is necessary to take effective action leading to solutions that eliminate sources of financialization. Scientists as well should learn to undertake accurate research of the objective functions of management processes and the role of money in these processes, rather than assert, the same way as the world's financiers and the Bilderberg Club, that since globalization progresses, its effect should be one world currency and a global institution having the right to issue it (among others, the Nobel laureate in economics R. A. Mundell believes a single world currency should be introduced [15]).

8. In researching the role of money in the economy, one should not forget that power over government is achieved by controlling the money supply. The future will show whether countries of the world will be able to free themselves from the power of bankers, or if it will remain as Rothschild stated: without a doubt, politics and finance have always walked arm in arm [10, p. 74].

\section{References}

[1] Bureau of Labor Statistics, USA, 2011.

[2] Central Statistical Office (GUS), Statistical Yearbooks for the Years 20072010, GUS, Warsaw.

[3] Central Statistical Office (GUS), Poverty in Poland in 2010, GUS, Warsaw 2011.

[4] Central Statistical Office (GUS), www.stat.gov.pl (30/05/2012).

[5] Dembinski P. H., Finance Following a Heart Attack, EMKA, Warsaw 2011.

[6] European Central Bank (ECB), Annual Report 2009, ECB, Frankfurt 2010.

[7] European Central Bank (ECB), Monthly Bulletin-May 2010, ECB, Frankfurt 2010. 
[8] Eurostat, www.eurostat.eu (7/30/2011).

[9] Hongbing S., Currency Wars, Wektory, Wrocław 2010.

[10] Hongbing S., Currency Wars 2, Wektory, Wrocław 2011.

[11] Kieżun W., Patbology of the Transformation, Poltext, Warsaw 2012.

[12] Kowalik T., Systemic Sources of this global crisis, "Master of Business Administration”, No. 5 (97) September - October 2009.

[13] Księżyk M., Labor costs in Poland Relative to EU Countries, "Managerial Economics” 2008 No. 4, pp. 43-52.

[14] Ministry of Finance, debt clock.

[15] Mundell R. A., Let's Create a Single World Currency (interview), "Polityka" March 21, 2009, No. 12 (2697).

[16] Otte M., When the Crisis Comes, Studio EMKA, Warsaw 2009.

[17] Polak E., Globalization and Socio-economic Diversity, Difin, Warsaw 2009.

[18] Skalniak F., Basic Problems of the Structure and Operation of Bank Credit in the PRL (habilitation), WSE, Kraków 1975.

[19] Sobieski Institute, Report of the Sobieski Institute, IS Nr.11.

[20] Stiglitz J.E., Freefall, PTE, Warsaw 2010.

[21] Strange S., Casino Capitalism, London 1986.

[22] Tittenbrun J., From the Rain into the Gutter. Meanders of Polish Privatization, Vol. 1-4, Poznań 2007.

[23] United States Constitution, USA.

[24] Walt T., Strong Mugs, "Polityka" No. 46 (2833), 8-15.11.2011. 